\title{
A China frente à globalização: desafios e oportunidades
}

\author{
VIKTOR SUKUP*
}

\section{Introdução}

A adesão da China à Organização Mundial do Comércio (OMC) em 2001 consolida a crescente abertura do país de maior população do mundo. Tal fato foi marcado por vários anos de difíceis negociações com os principais parceiros internacionais, Estados Unidos e União Européia, com os quais teve que concluir prévios acordos sobre as modalidades concretas da mútua abertura das economias. Foi celebrada, portanto, mesmo que de maneira superficial, como uma forma de triunfo final da economia de mercado. Após mais de vinte anos de reformas liberais, acabou oficialmente o tradicional isolamento do maior dos países que, até tempos recentes, estava ainda bem fechado. A China será agora mais um parceiro da ordem global, embora de peso e natureza bem particulares. O acontecimento, com certeza, é histórico, pois amplia ainda mais a controvertida "globalização da economia” e dará à China um papel de destaque no mundo do século XXI, maior do que se tivesse ficado à margem da OMC. O comércio mundial e a divisão internacional do trabalho estão de parabéns com a inclusão de pleno direito da China. Ademais, sua adesão à OMC - simultaneamente à de Taiwan - chegou quase como uma notícia de salvação após uma série de golpes desastrosos para a globalização liberal como o fiasco de Seattle, o escândalo da Enron, a queda da new economy e até os ataques de 11 de setembro e a posterior "guerra antiterrorista”. Tudo isso, conjuntamente com as simultâneas crises agudas da América Latina e do Oriente Médio, agravou sensivelmente o mal-estar econômico e as tensões políticas mundiais. Então, foi possível dar um novo otimismo, com certeza relativo, aos projetos de um "multilateralismo" renovado ${ }^{1}$.

Os pragmáticos chineses parecem nutrir a idéia básica que permitiu no passado os êxitos do Japão e dos "tigres asiáticos”: integrar-se ao mundo ainda dominado pelo Ocidente de maneira dinâmica, mas prudente, negociada e não imposta, sem deixar-se dominar.

Com um quinto da população da terra, uma economia e um comércio exterior já equiparado aos do Japão, os chineses pensam, com alguma razão, que só podem

* Ex-professor de economia latino-americana, européia e internacional da Universidade de Buenos Aires. 
ser parceiros em condições de igualdade com as outras grandes potências, e não subordinados a estas. O "comunismo chinês", no fundo, sempre foi talvez mais "chinês” do que “comunista”. Isto é, nacionalista e herdeiro de uma tradição milenar que considera a China não apenas como um país qualquer, mas como a civilização central da humanidade. Como salienta Eric Hobsbawm no seu olhar sobre o século $\mathrm{XX}$, apesar dos seus atrasos e misérias, a China nunca teve os complexos de inferioridade cultural tão típicos da URSS e de outros países socialistas que queriam a qualquer preço "alcançar e ultrapassar" os países capitalistas avançados². Foi essa também, sem dúvida, a razão principal da ruptura sino-soviética, pois na época esse "modelo" ainda parecia bem-sucedido.

Em todo caso, os chineses preferem hoje um mundo realmente multipolar à hegemonia de uma superpotência. Daí as tensões recorrentes com os Estados Unidos e a importância que dão às suas relações com a Europa, o Japão, a Rússia, o Brasil etc. Assim, a entrada na OMC constitui não tanto a conversão do Império do Meio ao capitalismo liberal, mas um compromisso pragmático aceito pelos líderes chineses para reforçar e consolidar as novas correntes de exportação, o aporte de investimentos externos direto (IED) que dinamizam sua economia e para deixar de uma vez de ser uma espécies de outlaw comercial $^{3}$. Ao mesmo tempo, as pressões exteriores, agora mais previsíveis visto que são "regulamentadas" no âmbito da OMC, continuam agilizando as reformas internas que os líderes chineses querem impor com o objetivo de avançar rumo à "economia socialista de mercado". Ademais, acrescenta um observador, a China pensa em "encontrar na OMC uma tribuna à altura de suas ambições geopolíticas ${ }^{4}$ ”, respaldada economicamente por um PIB quadruplicado em apenas duas décadas, período pelo qual a China entrou no segundo grupo de "tigres" ou “dragões"5 por meio das "quatro modernizações" muito bem-sucedidas de Deng Xiaoping (agricultura, indústria, ciência e tecnologia e defesa). Contudo, entrou nesse grupo com duas particularidades: mantém uma ideologia oficial totalmente diferente, comunista até no nome do partido dirigente, embora pouco compatível com a atual realidade social, e tem uma população que, sozinha, é bem maior que o conjunto de todos os demais países do Leste e Sudeste asiático, incluindo Indonésia, Filipinas, Vietnã e Birmânia.

É difícil prever a ideologia e a política econômica da China de amanhã. Entretanto, dado seu peso demográfico e agora também econômico e político, não há dúvida de que a China será um ator essencial no cenário mundial do século XXI. Para os demais países do mundo, e em primeiro lugar os países vizinhos, isso representa um desafio considerável de concorrência e também um fator de dinamização. Antes era o Japão, agora é cada vez mais a China que atua como locomotiva econômica regional. Para o resto do mundo, ela se apresenta ao mesmo tempo como um desafio e uma oportunidade ainda maior que o Japão das décadas de 60 a 80. Não é estranho que os empresários ocidentais, frente à conjuntura pouco satisfatória de seus países, entusiasmem-se ao falar das possibilidades de 
expansão no "maior mercado do mundo", nem que muitos deles tenham medo das futuras avalanchas de têxteis e outros produtos baratos provenientes da China. Isso será um grande desafio para os países menos desenvolvidos como os da América Latina. Independente de qual seja o papel da China no mundo de hoje e de amanhã, este só poderá ser compreendido, evidentemente, com uma rápida olhada sobre sua história.

\section{Do “Império do Meio” à China moderna}

“Quando a China despertar, o mundo se comoverá” profetizou Napoleão há dois séculos. Décadas depois, Marx imaginou, em uma antecipação genial, um Extremo Oriente dinâmico frente a um capitalismo ocidental maduro, acossado ao mesmo tempo pela luta revolucionária dos seus proletários e pela crescente concorrência com o capitalismo oriental. Na sua época, a China estava ligada ao mundo ocidental por uma espécie de colonialismo coletivo das potências dominantes, cujos símbolos eram as importações forçadas de ópio e as guerras a elas relacionadas. Conseqüências da terrível decadência chinesa foram as revoluções, os distúrbios e as guerras que, durante o século XX, fizeram surgir, no Ocidente, o espectro do "perigo amarelo".

Com aproximadamente 1,3 bilhão de habitantes - duas vezes e meia a população da América Latina, mas com apenas metade do território total e em grandes extensões inabitável - a China possui $21 \%$ da população mundial. Esta proporção é semelhante à que tinha no início da era moderna. Há cinco séculos, a China contava com aproximadamente cem milhões de habitantes. Naquela época, porém, o nível de vida e de desenvolvimento geral era mais elevado que o da Europa e, já no século XIX, seu PIB era seis vezes superior ao da Grã-Bretanha segundo cálculos de um conhecido especialista de história econômica mundial ${ }^{6}$.

"No decurso dos três séculos da Primeira Ordem Econômica Mundial”, sintetiza um analista argentino referindo-se nesses termos ao período entre os séculos XVI e XVIII, "na China, como nos impérios otomano, persa e mongol, interromperam-se os processos de transformação que tinham colocado estas grandes civilizações nos mais altos níveis de desenvolvimento econômico e cultural. Tinha-se assim criado o cenário propício para a crescente penetração européia no espaço chinês ${ }^{7}$ ".

Durante a primeira metade do segundo milênio, a China era mais avançada que a Europa, que mal começava a sair da Idade Média. Isso é válido até mesmo no plano tecnológico. Entre as invenções chinesas destacam-se o papel, a imprensa, a bússola e a pólvora. Todas, após serem logo utilizadas e aperfeiçoadas numa modernização conquistadora, tornar-se-iam instrumentos essenciais da dominação européia sobre o mundo. Para o Ocidente, a fechada e enigmática China poderia tanto ser uma parceira, uma rival ou uma inimiga. De todo modo, era o único país 
no Oriente e no mundo que poderia ser considerado como "igual”, quando não “superior”, descartada a outra principal civilização asiática, a Índia, por sua notória heterogeneidade interna, causa principal da sua fácil conquista pelos ingleses.

Quando chegaram os portugueses por via marítima como primeiros europeus, não foram recebidos com manifestações de amizade ${ }^{8}$. Junto aos recémchegados, contudo, predominavam juízos positivos. Os visitantes ficaram muito impressionados com o império chinês, "merecedor da maior admiração e do mais profundo interesse, não só por sua enorme extensão e sua incrível riqueza, mas também pela forma eficiente como tinha conseguido superar os principais problemas materiais ${ }^{9 ”}$. Logo houve relações comerciais pacíficas entre os chineses e os portugueses instalados desde 1557 no minúsculo território de Macau e importantes intercâmbios culturais e científicos, mutuamente benéficos, protagonizados pelos jesuítas que foram a Pequim passando pelo porto português ${ }^{10}$.

Durante os séculos seguintes, os contatos foram muito limitados, porém lucrativos, canalizados por Macau e logo depois por Cantão e Hong Kong, todos situados no delta do Rio das Pérolas. A porcelana de alta qualidade é chamada, em inglês, até hoje de "China-ware" e o chá se tornou inseparável dos costumes britânicos. A China, por outro lado, adaptou o milho, que hoje ocupa grandes extensões de terra no norte do país, e os red chillies, típicos da cozinha temperada de Sichuan. Em contraste com esse brilho chinês de civilização, a fundação de Hong Kong não foi um título de glória para a civilização ocidental. Nesse entreposto de comércio internacional a civilização ocidental revelou suas piores características: a fundação foi conseqüência da primeira Guerra do Ópio (1840-42), fundamental para impor o moderno narcotráfico capitalista, negócio considerado pelos ingleses necessário para pagar as importações de chá, seda e porcelana da China.

O Império do Meio não tinha interesse nenhum em estreitar relações com o Ocidente. Em 1793, em plena revolução industrial inglesa, o imperador Qian Long escreveu ao rei Jorge III: “o nosso Império Celestial possui todas as coisas em abundância prolífica e não carece de nenhum produto de dentro de suas fronteiras. Não tem por isso nenhuma necessidade de importar produtos manufaturados”. Tinha bastante razão, comentou Bertrand Russell, visto que a China era totalmente auto-suficiente, praticamente invencível militarmente e rodeada de povos comparativamente bárbaros ${ }^{11}$. E como foi visto, naquela época a China ainda era um país bastante rico, tendo como problema o fato de que, no plano tecnológico e conseqüentemente também no industrial, já tinha ficado bem para trás.

Durante esse período e até o final do século XIX, a China permaneceu praticamente fechada: "há séculos a China vive muito isolada, reclusa em suas tradições e na contemplação de sua grandeza passada, orgulhosa da sua imobilidade e desdenhosa dos bárbaros do Ocidente" descreveram dois especialistas franceses no ano de 1900. “A civilização moderna, barulhenta, expansiva e conquistadora 
por necessidade econômica vinha bater às portas hermeticamente fechadas do Império Celeste. Invadia a Índia, começava a conquistar a Indochina, penetrava pelo Norte até a ribeira do Pacífico, transformava em poucos anos o Japão. As raças européias povoavam o mundo. A América e a Oceania animavam-se com uma nova vida, a África livrava seus segredos, mas a China seguia sendo virgem de todo contato estrangeiro. Parecia que o povo mais antigamente civilizado devia ser, também, o último a adotar os procedimentos e as modas da nova civilização ${ }^{12}$ ”. Como se veria, tal imobilismo se tornou perigoso.

Segundo a famosa frase de Marx e Engels no Manifesto, o capitalismo tinha que forçar, por necessidade histórica, as muralhas da China com sua produção industrial moderna. Todavia, a China havia mostrado muito pouco interesse nesses produtos, como ainda confirmou em 1900 um observador inglês: “os chineses têm o melhor alimento do mundo, o arroz; a melhor bebida, o chá; e a melhor roupa, de algodão, seda e peles. Possuindo tudo isso e inúmeros outros produtos locais não necessitam comprar nada dos outros países nem por um penny ${ }^{13}$ ”.

Esta auto-suficiência, certamente, não excluía influências exteriores nem violentas crises e fomes desastrosas. Assim, a rebelião massiva dos Taiping nos anos 1850 e 1860, dirigida por um líder que se acreditava ser irmão de Cristo, teve conseqüências devastadoras, com milhões de mortes em grandes regiões do Sul e do Leste do país, enfraquecendo ainda mais um país já muito debilitado.

A situação geral, e com ela o relativo isolamento, mudaria rapidamente: entre 1895 e 1913, a rede ferroviária foi ampliada de apenas 200 para quase 6.000 milhas e o comércio exterior mais que triplicou nesse mesmo período ${ }^{14}$. Todavia, a China ainda representava apenas 1,5\% do comércio mundial em 1896-98, 1,7\% em 1911-13 e 1,9\% em 1921, ao passo que entre 1896-98 e 1911-13 a participação da Índia aumentou de 3 para 3,5\% e a do Japão de 1 para 1,6\%. Comparando o comércio exterior per capita, o da Índia equivalia ao dobro e o do Japão a dez vezes o da China ${ }^{15}$. Devido à maior integração mundial por meio do colonialismo, a Índia, em 1950, tinha aproximadamente quatro vezes mais estradas de ferro per capita que a China semicolonial, 16 e 4 centímetros respectivamente ${ }^{16}$.

Assim, uma maior abertura terminou por levar ao colapso a civilização chinesa como afirma um observador norte-americano: "os fuzis europeus que arrasaram as fortalezas de Cantão e logo abriram o caminho a Pequim fizeram mais do que aniquilar as barreiras do isolamento da China. Socavaram a sua civilização, tiraram-na também de sua órbita e puseram-na numa nova e perigosa posição no mundo, criando, assim, o que hoje é o problema do mundo. (...) O destino de um quarto da raça humana tem que afetar toda ela ${ }^{17}$ ”.

Os japoneses tiveram uma história muito diferente no seu encontro com o Ocidente. Souberam, após mais de dois séculos de isolamento quase total, pôr-se à altura do Ocidente, sem abandonar sua cultura, que é amplamente herdeira da chinesa: tecnologia ocidental e mentalidade japonesa, como resume o subtítulo 
de uma obra sobre o tema ${ }^{18}$. A mesma fórmula teria podido, provavelmente, salvar os chineses de muitas misérias. Deve ter sido isso o que pressentiu o almirante japonês em sua carta ao antigo amigo e então adversário almirante chinês na guerra sino-japonesa de 1894: se vocês não mudarem e não se abrirem ao Ocidente para aprender com ele, advertia, vão afundar ${ }^{19}$. E foi isso o que aconteceu.

A queda do Império e a Primeira Guerra Mundial constituíram um divisor de águas de acordo com dois demógrafos franceses: "a China atravessava uma profunda crise que refletia em sua situação demográfica. Os recursos proporcionados pelo solo pareciam ter chegado a seu limite máximo, dando lugar a uma situação malthusiana. A solução podia residir talvez na redução dos nascimentos combinada com a emigração ou em uma revolução da economia que proporcionasse novos recursos e possibilidades de aumentar a importação de alimentos paralela a elevação do número de empregos ${ }^{20}$ ". Isso, combinado com a traumática entrada do país no que então ainda não se chamava de "globalização", mas que já exigia adaptações bem difíceis, foi o estopim estrutural do fim do Império, das guerras civis dos anos 20 a 40, da queda de Chiang Kai-Shek e da revolução vitoriosa em 1949.

\section{A China contemporânea, um gigante em marcha: de Mao a Deng}

Desde 1979 e sob a liderança do veterano dirigente Deng Xiaoping falecido em 1997, a China começou a se colocar na órbita da "modernização" e da economia "globalizada”. Porém, convém aqui lembrar que a China já tinha bastante experiência em mudanças radicais: durante o século XX passou por mais revoluções que qualquer outro país importante do mundo, desde o capitalismo semicolonial desenfreado das primeiras décadas do século XX até a recente abertura, passando pelas guerras civis, a guerra de libertação nacional contra o Japão, o regime de Mao com suas coletivizações e a "Revolução Cultural”.

Uma das grandes perguntas sobre a China contemporânea é a da verdadeira herança dos 27 anos de Mao Zedong no poder. Com seus êxitos, erros e aberrações e com todas as suas mudanças de rumo, essa época em que a China era mais uma vez um país quase totalmente fechado preparou o terreno para o país de hoje. Aliás, o que às vezes se esquece, segundo avaliação oficial posterior, $70 \%$ da política implementada por Mao era correta e só 30\% errada. Mao tem lugar de honra, seja no museu de cera de Pequim, seja com seu enorme retrato na Tienanmen (Porta da Paz Celestial), seja ainda com um mausoléu na Praça de mesmo nome. A descrição que fez Alain Peyrefitte há quase 30 anos em seu famoso livro ${ }^{21}$ pode ser, em muitas das suas páginas, entusiasta demais, pois ele, como ministro do governo de De Gaulle, foi um convidado especial a quem os organizadores mostraram evidentemente os melhores aspectos do país. Todavia, o enviado do general foi sem dúvida um bom observador e certamente não podia simpatizar com o maoísmo. Ainda assim, no seu balanço da época, salienta os importantes 
progressos realizados nas áreas de desenvolvimento industrial e agrícola, de educação e cultura, nas infra-estruturas físicas e sociais, na situação da mulher, etc.

Para Gilbert Etienne, especialista em temas indianos e chineses, a comparação entre ambos os países em 1989 era favorável à China no desenvolvimento industrial, mas não na agricultura. Acrescentou, contudo, que é difícil mensurar as perdas humanas, em ambos os casos, por violência e miséria ${ }^{22}$. Por sua vez, o economista paquistanês Mahbub Ul Haq considerava a China como modelo à rejeição do consumismo ocidental e aspiração a uma maior justiça social ${ }^{23}$. De todo modo, cabe perguntar se o enorme dinamismo chinês desde 1979 não deve muito à revolução social e econômica das décadas anteriores que, apesar de suas falhas e até desastres, significaram um "grande salto para frente" nos diversos aspectos salientados por Peyrefitte. Nessa perspectiva, seria interessante estabelecer algumas comparações com o Japão da época Meiji ou ainda com os Estados Unidos do século XIX, quando medidas protecionistas, nation building, construção de estradas de ferro, progressos em educação e aprendizagem tecnológica, entre outros fatores, transformaram estes países em grandes potências industriais e militares.

Para os autores espanhóis de um livro bem documentado, o balanço do maoísmo é bem complexo: infra-estrutura, casas e bens de consumo relegados ao segundo plano, razoável crescimento econômico e transformação da China em um grande produtor de aço. "O gigante asiático desenvolveu-se sem dependências exteriores e tornou-se uma grande potência industrial. Em uma perspectiva social, logrou reduzir seu dramático nível de pobreza, introduzir melhorias educativas e sanitárias, rompendo, ademais, com algumas das ancestrais tradições chinesas. Por exemplo, cobrou-se importância do papel da mulher e alentou-se sua participação política e social (...). Mao, apesar do extremismo de suas idéias e de seu método, fez com que a economia crescesse a um índice anual de 5\%, unificou o país, tirou a China do legado feudal, das míticas dinastias imperiais e assentou as bases para a modernização do país ${ }^{4}$ ".

Desde a chegada de Deng dois anos após a morte de Mao, a economia chinesa, quase totalmente fechada desde 1949, abriu-se rapidamente e mostrou uma das maiores taxas de crescimento do mundo, ao redor de $10 \%$ por ano. Todos os observadores concordam que o nível de vida do chinês médio melhorou substancialmente, especialmente entre os agricultores. Não só a comida é hoje relativamente abundante, mas também as bicicletas, os aparelhos de televisão e outros itens estão agora muito acessíveis à massa camponesa. A eletrificação, indicador essencial da eliminação da pobreza, seria hoje comparável à dos países mais adiantados, chegando a $98-99 \%$ da população. A fome, muito presente nas primeiras décadas da República e ainda existente nos anos de Mao - sobretudo como conseqüência do caos do "Grande Salto para frente" que fez milhões de 
vítimas - parece ter desaparecido. A dieta dos chineses, tão adeptos à boa comida, tem sido nitidamente diversificada.

As tensões derivadas desses mesmos progressos, combinadas com uma estrutura política rígida de partido único, levaram a uma séria crise política. Estudantes e intelectuais, em particular, reivindicaram uma "quinta modernização", a da política. Apesar do massacre da Praça da Paz Celestial em 1989 e as sanções ocidentais subseqüentes, os Investimentos Externos Diretos (IED) - de fato, como veremos, a maioria destes não é tão "estrangeiro" porque são provenientes de Hong Kong e Taiwan - cresceram de apenas 3-4 bilhões de dólares por ano no início dos anos 90 para dez vezes mais durante o resto da década. Isso se deve tanto às reformas como ao contexto geográfico. A China está "na interseção de duas das mais importantes tendências das últimas décadas do século XX: o colapso do comunismo e o surgimento da Ásia oriental como o maior centro de produção industrial no mundo ${ }^{25}$ ". Ilustrando este último ponto, entre 1970 e 1990, a participação da China no mercado mundial saltou de 0,6 para 2,0\%, relativamente mais - a partir de um nível muito mais baixo, é verdade - que o Japão e de maneira semelhante aos “quatro tigres” que passaram, respectivamente, de 5,9 para 7,7 e de 2,5 para 7,0\% ${ }^{26}$.

Em 1995, a China já respondia por cerca de 3\% das exportações mundiais, mais do que Taiwan e a Coréia do Sul ${ }^{27}$. A participação chinesa nas exportações mundiais de produtos manufaturados aumentou de 0,8 para 3,6\% entre 1985 e 1995, enquanto a da Coréia do Sul passou de 2,2 para 3,2\% e a de Taiwan de 2,4 para 2,9\%. Contudo, nessa década, o nível salarial da indústria permaneceu em apenas 1,5\% daquele dos Estados Unidos, enquanto o dos “tigres” já oscilava entre $10 \%$ e 40\%, segundo estimativas do semanário britânico The Economist ${ }^{28}$.

Não seria completo este panorama do desenvolvimento recente da China sem uma breve referência aos "tigres”. Lembremos que dois deles são chineses, sem contar Cingapura que, mesmo distante geograficamente, tem três quartos de população chinesa. O êxito de Hong Kong, historicamente, está ligado mais à sua situação geográfica que a outros fatores: "Hong Kong é uma das cidades-Estado mais bem-sucedidas da história mundial. Deve seu êxito, contudo, não à sua genialidade ou à sua visão de futuro, mas à boa sorte, a seu colonizador e à revolução comunista na China. Os mais de 6 milhões de chineses de Hong Kong fizeram um excelente uso das oportunidades oferecidas a partir de 1949. Nunca, nem na Veneza da Baixa Idade Média ou na Amsterdã do século XVII, tanta riqueza havia sido acumulada em tão pouco tempo. Hong Kong deve seu êxito à sinergia entre a oportunidade e a capacidade de adaptação dos chineses com o rule of law e a estabilidade do ‘despotismo esclarecido’ do domínio colonial britânico. ${ }^{29}$ ” O “modelo econômico" propriamente dito foi - como salientam os que pretendem ver ali um ilusório modelo a seguir - muito liberal, ao contrário dos demais “tigres”, mas não deixou, contudo, de incluir elementos dirigistas essenciais: a administração colonial teve um papel bem ativo nos domínios dos transportes públicos e na habitação, 
ambos particularmente importantes no contexto de um território muito montanhoso, dividido em várias ilhas e uma península e com uma densidade demográfica que ultrapassa atualmente os 6.000 habitantes por $\mathrm{km}^{2}$. Por último, mas sem esgotar a lista das causas do "milagre” local, devem ser levadas em conta as tradições comerciais e portuárias, a afluência de mão-de-obra barata assim como de know how empresarial entre os milhões de fugitivos da República Popular que chegaram a Hong Kong.

Taiwan esteve sob governo continental por mais de dois séculos, antes de 1895, e apenas por quatro anos depois dessa data (1945-49). Suas "veleidades de independência” têm, portanto, alguns fundamentos na história, não apenas em seus êxitos pós-1949. Outros foram os fatores que fizeram da ilha "formosa" - segundo seu velho nome português - uma pequena potência industrial: importante ajuda inicial norte-americana nos planos militar e econômico, reforma agrária radical, política de industrialização pragmática baseada em uma sinergia entre mecanismos de mercado e fortes elementos de orientação estatal, inclusive com um importante setor público, integração hábil aos mercados mundiais em expansão, altas taxas de poupança e aprendizagem tecnológica acelerada. Outro elemento explicativo pode ser o meio século de colonização japonesa que deixou, como na Coréia, algumas infra-estruturas (estradas de ferro, portos, etc.) e alguns setores produtivos relativamente avançados. A própria precariedade da política exterior contribuiu para criar uma pressão pela luta por uma maior competitividade econômica, semelhante a países divididos como, por exemplo, a Coréia do Sul.

\section{Problemas e preocupações}

Que a época de Deng e de seus atuais sucessores foi muito bem sucedida em termos gerais quase não resta dúvida, todavia, como nos outros países asiáticos que mostraram um enorme dinamismo nas últimas décadas, nem tudo ocorreu do melhor modo. Tentemos analisar, de maneira sucinta, os principais problemas que acompanharam o progresso das últimas décadas e até que ponto eles poderiam impor algumas mudanças de rumo.

\section{a) Desequilíbrios sociais e regionais}

Obviamente, os problemas sociais e regionais estão interligados, além de só poderem ser analisados relacionados ao modelo de desenvolvimento e às posições da China frente à globalização. Incidem também nas relações exteriores, por exemplo, por meio das tensões entre governo central e a minoria muçulmana. Para apreciar as suas dimensões globais, será útil aqui uma perspectiva histórica e comparativa. Assim, Paul Kennedy lembra que nos Estados Unidos a diminuição da população agrícola a seu atual nível de 3\% da população total deu-se num 
contexto de crescentes empregos alternativos ao longo de mais de um século. Entretanto, como seria este processo na China ou na Índia, com cerca de 80\% de população agrícola, se houver aumentos acelerados da produtividade? Poderia haver então, adverte, manifestações de descontentamento bem mais violentas nesses países que o que se tem visto em outras partes ${ }^{30}$. A abertura da China poderia ter conseqüências imprevisíveis, o que explica sem dúvida sua prudência no campo das importações agrícolas. Já se fala hoje em um desemprego virtual de 150 milhões na população agrária chinesa. Se os chineses representam uma proporção importante entre os recentes refugiados econômicos na Europa, como nas últimas vagas de sans papiers da França, isso tem que ver, obviamente, com a situação nos seus lugares de origem.

Não está claro, em todo caso, como se absorverá a enorme massa de mão-de-obra, que continua crescendo em cerca de quinze milhões de pessoas por ano. Não está claro se o geralmente ineficiente setor estatal que, em 1994, ainda cobria $74 \%$ do emprego e $57 \%$ do investimento, mas participava com apenas $34 \%$ na produção industrial, será reformado ${ }^{31}$. A ineficiência deve-se, sobretudo, ao fato de "as empresas estatais operarem em indústrias pesadas e declinantes, estarem cheias de maquinarias e equipamentos velhos e manterem pessoal inflado, impedindo-as de competir no mercado livre" ${ }^{32}$. É verdade que a porcentagem das empresas estatais na produção industrial tem decrescido fortemente, de $76 \%$ em 1978 para $28 \%$ em $1999^{33}$, mas não sem crescentes problemas de desemprego urbano, agravados pela afluência de camponeses pobres que fogem do campo para buscar melhor sorte nas cidades. Porém, convém lembrar que, como descreve um conhecido autor estadunidense, a tendência global, que ilustra diariamente as notícias sobre racionalizações e fusões de empresas com milhões de empregos perdidos, é rumo à agricultura sem camponeses, à indústria sem operários e aos escritórios sem empregados ${ }^{34}$.

O êxodo rural acelerado faria crescer ainda mais as cidades, muitas das quais já ultrapassam os cinco milhões de habitantes, aumentaria os problemas sociais e a poluição atmosférica que já atinge níveis preocupantes: “a delinqüência está crescendo, o crime organizado floresce, os casos de furto simples se multiplicam e há algum tempo um verdadeiro banditismo tornam inseguras as estradas de várias províncias (...), o excesso de força de trabalho sem qualificação ameaça o equilíbrio social nas cidades”, advertia já, há uma década, um diário suíço liberal, sempre favorável às reformas desta orientação $0^{35}$.

Embora haja um aumento geral do nível de vida, essas pressões só vêm a agravar as desigualdades sociais já bem pouco compatíveis com o ideal "socialista”, ainda que seja "socialista de mercado". Segundo dados oficiais, o coeficiente Gini teria aumentado de 0,21 em 1978 para cerca de 0,45 atualmente. Isso provoca propostas, nesses mesmos círculos oficiais, de aumentar fortemente os impostos para reduzir as desigualdades ${ }^{36}$. Por outro lado, ao estimular o consumo interno, a 
política econômica muitas vezes facilita o aumento do consumo supérfluo, como de carros de luxo, considerado necessário para manter o dinamismo atual.

Entre a cidade de Xangai e a província mais pobre de Guizhou no sul do país, a diferença de renda per capita é de 10 para 1, e entre províncias "ricas” e "pobres" a disparidade geral ultrapassa a relação de 3 para 1 . A região costeira, com cerca de 37\% da população, aumentou, entre 1987 e 1994, sua participação de 51 para $60 \%$ na renda nacional, de 60 para 67\% na produção industrial e de nada menos que de 60 para 85\% nas exportações. Estes aumentos concentraramse no período 1990-94, portanto nos anos de rápido aumento dos IED. Houve, de fato, uma ligeira diminuição entre 1987 e 1990, salvo o caso das exportações, o que se deduz que se acentuaram fortemente os aspectos desequilibrantes do crescimento na fase mais recente. As diferenças de renda entre os $20 \%$ mais ricos e os $20 \%$ mais pobres da população foram estimadas recentemente pelas Nações Unidas a uma relação de 6,5 para 1 , semelhantes às de outros países asiáticos, porém maiores que na Coréia do Sul, na Índia e na Indonésia, ainda que muito inferiores às dos países latino-americanos. Tais diferenças teriam diminuído no período 1978-85 e logo aumentado significativamente ${ }^{37}$.

Os desequilíbrios entre regiões costeiras e interiores são semelhantes àqueles existentes entre agricultura e indústria. Alguns observadores pensam que estes desequilíbrios entre as regiões do Sul costeiro, sede das novas atividades industriais impulsionadas pelas reformas liberais e o pelo capital estrangeiro, e as do interior, relativamente estagnadas e mais agrícolas, ameaçam seriamente a unidade nacional. Por isso, no Ocidente supõe-se que essa unidade seja muito frágil. O sinólogo alemão Oskar Weggel salienta, por outro lado, as diferenças históricas entre ambas macro-regiões, caracterizadas por profundas distâncias (cultura "amarela" e cultura "azul”), sendo a costeira por tradição muito mais aberta às influências do exterior e aos intercâmbios comerciais com outros países. Este contexto explica também, conjuntamente com outros fatores, o dinamismo de Hong Kong e de Taiwan, hoje imitados pelas regiões vizinhas das "zonas econômicas especiais” da China meridional ${ }^{38}$.

Uma das grandes preocupações chinesas, salientadas também no testamento de Deng Xiaoping, é o futuro dos grupos étnicos minoritários que representam pouco mais de $5 \%$ da população total, mas que ocupam a metade ocidental do país, em particular o Tibet e Xinjiang. Os tibetanos budistas continuam afetando negativamente a imagem da República Popular no mundo, que tende a acreditar mais na dura crítica de Dalai-Lama que na versão oficial de uma coexistência pacífica e progressista. O problema principal, contudo, parece ser o dos uighures de Xinjiang, povo de língua aparentada do turco e de religião muçulmana, frente à imigração, assim como no Tibet, dos chineses han majoritários que já os reduziram nas últimas décadas de grande maioria regional para menos da metade da população. Houve, nos últimos anos, crescentes tensões, com 
enfrentamentos armados e atentados. Se a China entrou na aliança contra o terrorismo internacional é devido a essa preocupação. Segundo ativistas uighures que aspiram a um “Turquestão oriental” independente ou alguma federação com os povos irmãos ex-soviéticos do outro lado da fronteira, os uighures da China poderão enfrentar, com êxito, mais de um bilhão de chineses han, a exemplo dos tchetchenos que, bem menos numerosos, têm desafiado os 150 milhões de russos ${ }^{39}$. Houve combatentes originados dessa região chinesa como com os talibãs capturados no Afeganistão pelos Estados Unidos, cuja extradição exige o governo chinês, até agora sem êxito. Para os Estados Unidos, estes não são comprovadamente “terroristas”. E também por estas razões, e para diminuir os crescentes desequilíbrios regionais constatados nos últimos 20 anos, as autoridades de Pequim têm lançado recentemente vários grandes projetos com vista a acelerar o desenvolvimento econômico do Oeste e melhor integrá-lo, como a estrada de ferro ao Tibet e o gasoduto Xinjiang-Xangai, além do aproveitamento do potencial hidroelétrico do Yang-Tze com a polêmica construção da represa das Três Gargantas perto de Chongqing. Também se pensa, nesse contexto, desviar no futuro parte das águas deste rio para as regiões setentrionais sempre expostas às secas ${ }^{40}$.

\section{b) Meio ambiente, agricultura, transporte e energia}

O meio ambiente nesse país tão densamente povoado na sua metade oriental encontra-se, inevitavelmente, sob fortes pressões diversas e isso não pode deixar indiferente o resto do mundo. Com $21 \%$ da população mundial, a China só dispõe de cerca de 7\% das terras cultiváveis. Passou a importar - apesar do forte aumento de sua produção agrícola - grandes volumes de cereais. Agravam-se a erosão dos solos e a contaminação do ar e das águas, já desastrosa em algumas grandes cidades e com repercussão sobre a saúde dos habitantes. É como salientou Lester Brown, diretor do Worldwatch Institute de Washington, há vários anos: “Em uma economia mundial globalizada, os preços crescentes de alimentos na China transformar-se-ão em preços crescentes para alimentos ao nível mundial e a escassez de terras na China chegará a ser a escassez de terra para todos ... ${ }^{41}$ ”. Talvez esta visão seja pessimista demais. Países como os do Mercosul terão, possivelmente, boas oportunidades de elevar as exportações. Em todo caso, isso ilustra um dos aspectos frágeis do "milagre chinês".

Paul Kennedy, em suas previsões para o século XXI, advertia, há mais de uma década, que o rápido aumento da produção de cereais parecia entrar em crise já no final dos anos 80. Não que a política agrícola chinesa esteja em um beco sem saída, salientou, "mas é difícil ver como pode a produção seguir aumentando para acompanhar o crescimento demográfico sem que haja desenvolvimento tecnológico que permita experimentar uma nova forma de revolução agrícola”. E acrescenta, aludindo às possíveis conseqüências sociais de uma modernização acelerada: “No 
estado atual das coisas, os obstáculos estruturais à semelhante revolução são gigantescos ${ }^{42}$ ”.

Transporte é um tema fundamental num país de extensão e de densidade demográfica como a China, tanto entre as suas imensas cidades como dentro delas. Quanto tempo suportará as grandes cidades chinesas, cujo rápido crescimento contribui, aliás, para reduzir a área agrícola e para a aceleração do consumismo de tipo ocidental, em particular a multiplicação dos carros particulares? Estes já fizeram que o tempo de transporte dentro de cidades como Pequim crescesse muito fortemente nos últimos anos, agravando a poluição do ar. Ao contrário dos países da América Latina e de outros, a China de Mao e de Deng tinha desenvolvido e modernizado maciçamente a sua rede de estradas de ferro - que se estendeu desde 1949 a mais do triplo, chegando a $70.000 \mathrm{~km}$ - conjuntamente com os meios de transporte por água e ar. Mas em tempos recentes, a construção de estradas tomou a dianteira e o peso relativo das estradas de ferro, ainda bem alto, diminuiu bastante. Segundo o ministério competente, entre 1990 e 2000, a participação das estradas de ferro no tráfego de passageiros desceu de 46 para 39\% e de 59 para $54 \%$ nos fretes $^{43}$. Em que condições de distribuição da renda nacional poderá ocorrer uma maior expansão da utilização do carro particular? E com que conseqüências ambientais? Não é o meio ambiente o único problema, claro, mas contribui para uma problemática ecológica global preocupante, que é salientada em todos os estudos sérios sobre a China atual.

Para dois analistas estadunidenses, “a industrialização de um país com uma população tão enorme como a China originará pressões sem precedentes sobre o meio ambiente global. Imagine uma China onde a maior parte da população use carros, ar condicionado e geladeiras. Hoje, a China já é o produtor de gases causadores do efeito estufa de maior crescimento e seu crescimento econômico agravará o aquecimento global provocando, provavelmente, o aumento do nível dos mares e inundando assim outras regiões densamente povoadas como o delta de Bangladesh. A industrialização da China aumentará os preços de energia em todo o mundo e criará problemas de contaminação como as chuvas ácidas, que afetarão, inclusive, países distantes ${ }^{44}$ ". Existem, assim, previsões de que a China será em 2020, ou ainda antes, o primeiro emissor mundial de dióxido de carbono, com aproximadamente $20 \%$ do total. Há meio século só contava com algo em torno de $1 \%$ e pouco mais que $10 \%$ em 1990.

Assim, embora se consiga travar o crescimento demográfico, o atual modelo chinês deve causar profundos impactos sobre o resto da economia e principalmente sobre o meio ambiente mundial. "O meio natural”, diz um analista espanhol, "tem sido uma das primeiras vítimas sacrificadas para assegurar um vertiginoso desenvolvimento baseado no lucro em curto prazo, mas que em longo prazo pode chegar a ser altamente desastroso ${ }^{45}$ ”. Dois outros autores espanhóis indicam como uma das causas do impacto ecológico do crescimento chinês sua forte dependência, 
ainda, do carvão como fonte de energia: a China é hoje o primeiro produtor mundial - sua produção passou de 30 para 500 milhões de toneladas entre 1949 e 1976, e para mais de 1.100 em 1990 - e o carvão, que representa três quartos do consumo energético do país, tem um alto componente de enxofre, contaminando fortemente o ar. $^{46}$

No que diz respeito ao abastecimento energético, a China é hoje também um grande produtor de petróleo, mas não está entre os supergrandes - Rússia, Arábia Saudita e Estados Unidos - e terá de importar volumes crescentes. Há vários grandes produtores relativamente vizinhos, mas longe de suas regiões industriais do Leste. O aproveitamento destes recursos implica, portanto, o financiamento de custosas infra-estruturas como gasodutos. A China tornou-se importadora nata de petróleo nos últimos anos e se prevê que o seu consumo aumentará, entre 2002 e 2010, de 230 para 300 milhões de toneladas, o que significaria aumentar de 6 para 8-10\% do consumo mundial; ao mesmo tempo, o de gás natural passaria de 20 para 75-100 bilhões de $\mathrm{m}^{3}$. Por isso, e para diminuir a sua relativa dependência do Oriente Médio, a China precisa de uma relação construtiva com os Estados herdeiros da antiga URSS. Assim, melhoraram notavelmente os laços com a Rússia de Putin e não quer ficar implicada nos conflitos do Oriente Médio. Vê com reticência compreensível as iniciativas dos Estados Unidos de reforçar o seu controle sobre as reservas de petróleo e sua presença na Ásia central e ocidental. Também teme, por razões de política interior já indicadas, o islamismo radical em terras vizinhas. Em todo caso, uma interrupção do abastecimento ou um forte aumento dos preços causariam problemas graves para seu dinamismo industrial, com conseqüências sociais perigosas ${ }^{47}$. Nesse contexto de procura de diversificação das fontes energéticas, um contrato de 8,5 bilhões de dólares acaba de ser assinado com a Indonésia para obter desse país enormes volumes de gás natural ${ }^{48}$.

Em 2000, a demanda energética chinesa já chegava a aproximadamente um bilhão de toneladas de equivalente-petróleo, quase o dobro da demanda do Japão e o triplo da Alemanha. Enquanto a demanda dos países europeus e do Japão pouco cresce devido a medidas de poupança energética, a China continua aumentando a sua. Isso gerará, inevitavelmente, pressões sobre o meio ambiente e sobre os preços de petróleo no mercado mundial.

Enchentes desastrosas dos últimos anos, como as de 1998 e de 2002, têm entre suas causas o desmatamento das terras altas do interior. Mas o problema central do futuro será, ao contrário, a escassez de água combinada com a da terra. Além disso, o capítulo dedicado à China de uma obra editada por distintas ONGs asiáticas destaca os seguintes problemas ambientais:

- a gigantesca represa das Três Gargantas sobre o rio Yang-Tsé provocará, possivelmente, impacto negativo sobre o clima, 
conseqüências incalculáveis no caso de terremotos, perdas importantes de terras de cultura, contaminação de águas subterrâneas e de superfície, salinização de terras, transformação de lagos em pântanos, etc.;

- acidentes industriais que, segundo números oficiais, matam mais de 20.000 pessoas por ano e freqüentes incêndios com numerosas vítimas;

- há também incontáveis problemas de meio ambiente nas "modernas" fábricas de capital vindo de fora, não poucas vezes com vítimas fatais, onde a saúde dos trabalhadores, em particular das trabalhadoras, sofre as conseqüências de práticas que privilegiam o lucro imediato ${ }^{49}$.

\section{c) Condições de trabalho, regime político, corrupção e condição feminina}

Estes últimos pontos nos levam a outros problemas agudos como as condições de trabalho muitas vezes deploráveis que, conjuntamente com outros fatores como um sistema político repressivo e uma corrupção difundida, cria tensões importantes.

Quanto aos aspectos repressivos, a China bate o recorde mundial em matéria de pena de morte e seu sistema jurídico-policial está, como a sua estrutura política, certamente muito longe das normas democráticas. Observadores falam de um sistema verdadeiramente imperial onde há, no fundo, relativamente pouca diferença entre as últimas dinastias do império Chiang Kai-Shek, Mao e Deng quanto à maneira autoritária de dirigir os negócios do país. Não existem mais aqueles "senhores da guerra" de então, mas sim existem os "pequenos imperadores" locais que podem ser grandes delinqüentes e gozam de uma impunidade absoluta por sua habilidade de administrar sem escrúpulos os fios do poder local. Mais do que de "marxismo-leninismo", sugere um observador, poderia hoje se falar de um "mercado-leninismo", quer dizer, de um capitalismo desenfreado combinado com um sistema que continua sendo muito autoritário, como o foi também, durante décadas, o de Taiwan ${ }^{50}$.

As condições de trabalho, em particular nas zonas econômicas especiais, lembram muitas vezes as descrições da época do capitalismo das origens industriais européias. Jornadas longuíssimas, inexistência, ou quase inexistência, de férias e de dias de descanso, salários baixíssimos e falta de segurança são aspectos típicos do trabalho em muitas dessas fábricas que sustentam o crescimento chinês. Como resume um autor, os êxitos da China como país exportador nos anos 90 se devem amplamente à "combinação de investimentos de Hong Kong e de Taiwan e condições de trabalho neo-dickensianas nos territórios satélites de Hong Kong no delta do Rio das Pérolas ${ }^{51}$ ”. Essas condições sugerem repor a velha questão: são apenas excessos de certos patrões inescrupulosos ou necessidades intrínsecas da acumulação de capital, como na Inglaterra de Charles Dickens e na França de 
Emile Zola? As fases iniciais dos países industriais haverão sempre de fulminar a obra de caridade? Será preferível ser explorado sem piedade por um patrão a não ser explorado por ninguém? Pode-se supor que sim, se isso significa uma miséria pior e sem saída, e aquilo uma melhora relativa que abre novas perspectivas, apesar de parecer herético a uma esquerda que se opõe ao aggiornamento necessário ${ }^{52}$. Mas é certo que tais condições de trabalho criam tensões e pressões para permitir sindicatos independentes e liberalizar o regime político.

A corrupção já era uma característica típica da China nos séculos passados e foi um dos fatores centrais que determinaram a queda da última dinastia e do regime de Chiang Kai-Shek. Nos anos 70, Alain Peyrefitte achava que entre as qualidades principais atribuídas aos dirigentes pela população salientava-se a sua honestidade. Mas, em tempos recentes, a partir da política de abertura, as coisas devem ter mudado radicalmente, porque o fenômeno tomou, segundo todos os observadores, uma dimensão extraordinária. Para um dos mais bem informados deles, o movimento reprimido em junho de 1989 na Praça da Paz Celestial foi sem dúvida tanto "pró-democracia” como "anticorrupção". "Se o Partido Comunista Chinês sofrer um colapso”, acrescenta, "a corrupção será seguramente a razão principal. Ademais, ela floresceu com a liberalização econômica e chegou a estar tão imbricada que em algum momento pode causar-lhe sérios danos. Se for possível que a China continental consiga manter seu milagre econômico e transformar-se em uma grande Taiwan, também é possível que a corrupção e o regionalismo a transformem em uma outra Nigéria”. Às vezes, acrescenta, a China aparece hoje mais como uma verdadeira cleptocracia que como uma autocracia ${ }^{53}$. Não seria o único caso de associação estreita de corrupção com abertura exterior: na América Latina há casos particularmente eloqüentes.

As mulheres tiveram na China, sabe-se, uma existência bastante triste em tempos imperiais. Com a chegada de Mao, houve nesse plano melhoras realmente revolucionárias. As conseqüências das políticas dos anos 80 e 90 foram várias. A política não exatamente liberal do filho único, imposta brutalmente para reduzir o crescimento demográfico, fez aumentar o número de nascimentos de crianças do sexo masculino em relação às do sexo feminino até em 15 a 20\% em algumas províncias. É fácil prever no futuro um agravamento de situações já hoje espantosas de tráfico de mulheres, raptos, etc. "Seria demasiado simplista dizer inequivocamente que as mulheres chinesas tenham perdido terreno nos anos 80 e 90”, resume uma observadora estadunidense de origem chinesa. "A economia de mercado lhes deu novas oportunidades e em alguns casos também independência. Mas, no total, parece-me que se as mulheres ganharam em uma escala absoluta, perderam, contudo, terreno relativo frente aos homens. Quando o Partido deixou de lutar pela igualdade, atitudes tradicionais voltaram a manifestar-se com maior força”. Isso levou, por exemplo, a que no Politburó, onde havia duas mulheres em 1978, não haja nenhuma desde fins dos anos 80 . No Comitê Central, sua proporção diminuiu 
de 11,1 para $7,5 \%{ }^{54}$. Nos últimos anos, com certeza, anunciaram-se medidas que tendem a suavizar a política do filho único.

\section{A “Área Econômica Chinesa”}

É importante salientar, em relação ao contexto regional e internacional da China, a cada vez mais estreita imbricação do que alguns autores chamam de "triângulo de crescimento da China meridional” ou de "Área Econômica Chinesa" que inclui as novas "regiões administrativas especiais” de Hong Kong e de Macau, assim como Taiwan. Com a incorporação de Hong Kong, o território da China aumentou $0,01 \%$ e a sua população $0,5 \%$, mas seu PIB cerca de $20 \%$ em dólares correntes (e quase $5 \%$ em paridades de poder aquisitivo). Com Taiwan, seria mais um aumento em torno de $40 \%$ (ou de quase 10\%). Em dólares correntes, o PIB conjunto desta “Área Chinesa” era, já em 1995, de 900 bilhões, pouco menos que o da Itália ou da Grã Bretanha, mas, calculado em paridades de poder aquisitivo, seria de quase 3,6 bilhões (quase 3,2 para a R. P. da China), contra 6,8 dos Estados Unidos e 2,7 do Japão $0^{55}$.

Os vínculos entre a República Popular, Hong Kong e Taiwan cresceram aceleradamente como conseqüência da abertura chinesa. Das exportações de Taiwan, a porcentagem destinada a Hong Kong passou de menos de 10\% em 1980 para mais de 20\% em 1993, ultrapassando em 1995 as que se dirigiam aos Estados Unidos. Desde 1995, uma manobra administrativa permite contornar a proibição de laços comerciais diretos pela criação bastante artificial de um porto off-shore em Taiwan, teoricamente fora do seu território aduaneiro. Ironicamente, após as eleições dos Presidentes Lee Teng-hui e Chen Shui-bian em 1996 e 2000 - consideradas ambas como provocações a Pequim e acompanhadas por fortes tensões bilaterais, inclusive militares -, as relações continuaram a intensificar-se ainda muito mais, não sem provocar temores em Taiwan de uma crescente dependência da ilha frente, a Mainland China, que tem quase 60 vezes mais habitantes e que nunca renunciou a seu “direito" de reconquistar a ilha, se necessário pela força. Algo semelhante passou com as exportações de Hong Kong, onde o mercado chinês superou o norte-americano no início dos anos 90. A China, que exportava porcentagens similares para Hong Kong e para o Japão em 1980, enviava mais de $40 \%$ do total ao enclave inglês em 1992, contra pouco mais de $10 \%$ ao Japão. No total, os três elementos desta "área chinesa” somavam 5,9\% das exportações mundiais em 1994, deslocando a França para o quarto lugar, ainda descontando, como se deve, as reexportações da China que constituem o grosso dos envios de Hong Kong ao exterior. Resumindo, a crescente interconexão de Taiwan, Hong Kong e a República Popular pelo comércio e os investimentos mútuos fazem surgir, independentemente das tensões políticas recorrentes, um gigante econômico que supera amplamente as cifras que correspondem apenas à China. 
A maior parte dos investimentos "estrangeiros” na China provém de Hong Kong e, em muito menor escala, de Taiwan. Por outro lado, a China Popular já é o primeiro investidor exterior em Hong Kong há vários anos ${ }^{56}$.

Um analista holandês não hesita em falar de uma forma de "Sociedade Anônima China, Hong Kong, Taiwan”. Como outros autores, refere-se à província de Guangdong, vizinha de Hong Kong, como um “quinto tigre”, e prevê a integração dos sistemas com a erosão do comunismo e a implantação de um sistema misto, entre a liberalização capitalista e outras alternativas neoautoritárias, neonacionalistas e neoconfucianas ${ }^{57}$.

Outros observadores também insistem na função do delta do Rio das Pérolas, com Macau por um lado e Hong Kong pelo outro, assim como Guangzhou (Cantão) a uns cem kilometros águas acima, como o motor regional da China meridional. Analizam os crescentes vínculos estreitos entre estes territórios, as "zonas econômicas especiais" adjacentes de Shenzhen e Zhuhai e o resto da província de Guangdong, assim como os enormes trabalhos recentes de infraestrutura - entre os quais, além de várias pontes e auto-estradas, os novos aeroportos internacionais de Hong Kong e de Macau, inaugurados em 1998 e 1995, respectivamente - na perspectiva das fórmulas de "regiões de administração especial” acordadas para Hong Kong a partir de 1997 e Macau a partir de fins de 1999. Estimam que esta região tem, e continuará tendo, grandes vantagens comparativas para o futuro previsível ${ }^{58}$.

Um pesquisador taiwanês confirma a tendência para a convergência entre as economias insular e continental no contexto regional do pós-Guerra-Fria: desde os antigos sistemas orientados, respectivamente, por uma "via chinesa SmithKeynes" e uma outra "via chinesa marxista-leninista", resume, o futuro irá para um "Smith-Marxist-Chinese model ${ }^{59}$ ". Entretanto, também é certo que, no campo político, com a queda do velho Guomindang como partido de governo em 2000-01 e até com revoluções divergentes, as coisas serão mais complicadas, sempre perigosas para a paz regional.

Uma das questões controvertidas é se o centro mais dinâmico da China futura será Xangai ou Hong Kong, e também se uma parte das funções desta cidade será transferida para Cingapura. A resposta talvez seja a seguinte: o exenclave britânico, com as instituições da "região administrativa especial” em princípio asseguradas até 2047, manterá, provavelmente por bastante tempo, uma importância primordial como centro comercial, financeiro, portuário e terciário da dinâmica região Sul e porta principal de entrada da China. Na medida em que o ambiente se torna pessimista, Cingapura poderia retomar algumas das suas funções internacionais. Xangai, em uma China que se abre mais ao mundo e onde mais pessoas começam a falar inglês, poderá, progressivamente, mas seguramente não em curto prazo, ser uma concorrente feroz. Num prazo previsível, ficará o enorme e moderno centro industrial e econômico que já é hoje, na parte Leste do país, 
muito mais perto de Pequim e outras cidades importantes; mas deveria, se Hong Kong não mostrar muita capacidade de se adaptar novamente às mudanças, pôr em risco cada vez mais a situação privilegiada da cidade do Sul. Um comentário suíço recente salienta que estão saindo dali postos de trabalho terciários para a vizinha cidade de Shenzhen e que deixam de afluir os IED, tendência que deveria ser reforçada pela adesão da China à OMC. Hong Kong, resume, "não ficou parada nos últimos anos, mas a dinâmica da China continental tem reduzido as vantagens relativas da cidade”, embora sua acelerada integração à província de Guangdong, origem de aproximadamente 40\% das exportações chinesas, poderá melhorar as suas perspectivas no futuro ${ }^{60}$.

\section{A China no mundo do século XXI - novo parceiro ou elemento perturbador?}

A longa trajetória de isolamento e de humilhações recebidas do Ocidente nos séculos XIX e XX e fatores como o seu imenso peso demográfico e sua cultura original fazem com que a China dificilmente seja um "parceiro normal” na ordem mundial. Terá suas próprias respostas aos desafios da globalização liberal que podem ajudar a corrigir certas aberrações da atual realidade mundial. Com efeito, na medida em que a China tenderá - por sua dupla condição de país já bastante industrial mas ainda "em desenvolvimento" - a compreender melhor que as outras grandes potências as necessidades dos países pobres, pode-se esperar que vá tomar posições mais favoráveis a estes no cenário internacional, como na OMC, ainda dominada pelos países ocidentais ${ }^{61}$. Seria imaginável, em médio prazo, uma forma de aliança anti-hegemonia norte-americana dirigida pela China e integrada por outros países do "Terceiro Mundo" como o Brasil, frente à qual a Europa, associada à Rússia, teria talvez uma posição de mediação entre o Norte e o Sul.

Para o sinólogo francês Lucien Bianco, Deng mudou mais a China em seus 18 anos no poder que Mao em 27, e em um sentido muito positivo de aproximação ao Ocidente. Mas o país não deixa de ser inquietante "para o resto do planeta, porque, se tiver êxito, deverá contar, em muito pouco tempo, não só com um mercado gigantesco mas também com a emergência de uma superpotência provavelmente despótica, imperialista e contaminadora ${ }^{62}$ ".

O armamentismo chinês - ou o que se vê de fora, pois os chineses salientam sempre o caráter defensivo das suas despesas militares - e seus numerosos conflitos com países da região, combinados com seu perfil de gigante frente a um grande número de países de dimensões mais modestas, não deixam, efetivamente, de preocupar muitos asiáticos. Se as tensões internas reclamassem um inimigo externo para desviar a atenção da população desses problemas, não seria difícil de encontrálo. "Em um mundo cheio de afirmações nacionalistas de pequenos Estados e grupos étnicos, (Deng) tem legitimizado novamente o nacionalismo de um país muito 
grande”, adverte um outro especialista francês, François Godement. "Com seus sucessores, as democracias terão que cooperar para permitir que a China leve a término sua modernização econômica e assegurar ao mesmo tempo que a clarificação de seus objetivos nacionais continue sem gerar ameaças para o resto da Ásia ${ }^{63}$ ".

Também, dois jornalistas norte-americanos especializados em temas chineses escrevem que o país, que já tem o maior exército do mundo, "está utilizando seu boom econômico para financiar um desenvolvimento militar que poderia desestabilizar toda a Ásia. A China mantém, com efeito, desacordos sobre suas fronteiras marítimas ou territoriais com nove de seus vizinhos, combateu com quatro deles no último meio século e parece estar reivindicando como seu todo o Mar da China meridional, incluindo nesse as rotas marítimas de maior importância como a do petróleo do Oriente Médio para o Japão. A China está se transformando em uma superpotência regional dominante de todo o continente (...) O Ocidente, em poucas palavras, ainda não começou a levar em conta as conseqüências da transformação da China em uma nação moderna: imaginem um outro Japão, mais com uma população superior em uma dúzia de vezes mais as armas nucleares ${ }^{64}$ ". Houve, também, uma aproximação notável entre a Rússia e a China, os dois gigantes territoriais da Ásia, o que deixa Pequim com uma margem de manobra bem maior nas suas relações com seus vizinhos do Sul. Mas em 2002, se há tensões perigosas na Ásia, elas certamente não provêm da China, e se o desenvolvimento chinês provoca preocupações para o meio ambiente mundial, o Ocidente, e particularmente os Estados Unidos, teriam interesse em mostrar o bom exemplo.

\section{Perspectivas e conclusões}

O aumento do comércio exterior e a afluência dos IED ainda continuaram, após a crise asiática iniciada em 1997, com apenas uma ligeira desaceleração. Em 1999 e 2000, os IED desceram do patamar de 45 bilhões de dólares para o de 40 bilhões, voltando ao anterior e ainda superando-o, com um recorde de 46,8 bilhões em 2001. O total dos anos 1979-2001 chegou assim a cerca de 400 bilhões. As exportações só aumentaram, de 183 para 195 bilhões entre 1997 e 1999, para logo saltar a 249 e 266 bilhões em 2000 e $2001^{65}$. O êxito parece inquestionável e a locomotiva ainda continua a todo vapor. Mas as duas grandes perguntas, a primeira formulada há mais de uma década e a segunda a partir de 1997, continuam, contudo, sendo as seguintes: poderá o híbrido da "economia de mercado socialista” de Deng Xiaoping sobreviver sem maiores alterações de seu arquiteto ${ }^{66}$ e seus sucessores imediatos? E como evolucionarão as diversas crises ao nível asiático e mundial?

Segundo a Unctad, ainda no contexto da atual crise mundial, a China continuou atraindo quase uma quarta parte dos IED, praticamente o dobro que o México que tinha substituído o Brasil como primeiro destinatário da América 
Latina ${ }^{67}$. Em 2001, as exportações chinesas atingiram umas quatro vezes mais do que uma década atrás, um aumento de quase $50 \%$ desde os anos 1997-98. Houve um ligeiro decréscimo no comércio mundial durante esse ano, conseqüência da recessão nos países industriais, da implosão da new economy bubble e dos vôos do 11 de setembro. Em 2002, segundo estimativas da OMC, ano em que o comércio mundial deveria voltar a crescer, mas apenas $2 \%$ em valor ( $1 \%$ em volume), as exportações chinesas já aumentaram no primeiro semestre a uma taxa impressionante de $17,5 \%$, frente ao aumento de $14,5 \%$ das suas importações ${ }^{68}$. Um dos principais setores é o de têxteis e vestuário, onde as possibilidades de expansão são ainda enormes ${ }^{69}$. Alguns se perguntam se a China não se tornará o alfaiate do mundo.

A entrada na OMC deveria reforçar estas tendências. Implica a liberalização não só das importações, mas também dos IED (acordos sobre serviços - GATS e propriedade intelectual - TRIPS - etc.) na participação em diversos setores até então fechados a estes, como telecomunicações, seguros, bancos, distribuição comercial e turismo, onde se pode esperar modificações importantes na eficiência e na estrutura de propriedade, assim como na legislação concernente aos serviços e a propriedade intelectual. ${ }^{70}$ Deve-se salientar, porém, que esta abertura aos IED se faz de uma maneira muito gradual, prudente e seletiva, ao contrário do que se fez por exemplo na Argentina dos anos 90. Estes acordos interessaram, em particular, a União Européia que pretende concluir o seu acordo prévio à adesão da China, como explica o Comissário competente no capítulo sobre estas negociações, cujo título otimista é eloqüente: “O futuro está na China”. ${ }^{71}$

A crise de 1997-98 tinha provocado uma queda catastrófica dos PIBs dos “tigres” da segunda geração e também da Coréia, mas só, como se viu, uma ligeira desaceleração na China. Este contraste tem a ver com o tamanho do país e a sua menor abertura financeira. Mas ainda assim existem perigos exteriores, não só no abastecimento energético, para a continuidade deste dinamismo. Uma recessão persistente nos principais mercados, asiáticos e outros, não poderia deixar de afetar as perspectivas de crescimento, apesar de prosseguir, como nos últimos anos, a expansão do mercado interno.

Um especialista espanhol fornece índices que ilustram a menor vulnerabilidade da China frente às crises exteriores recentes: a dívida externa em curto prazo, favorecida pela abertura financeira e a especulação, chegou a ser bem superior (entre 1,5 e 2 vezes, aproximadamente) às reservas de divisas na Tailândia, na Indonésia e na Coréia às vésperas da crise de 1997, mas só a uma oitava parte das reservas no caso da China; a eficiência dos novos investimentos era bem maior na China que na Malásia e na Tailândia e a sua moeda tinha se depreciado menos $^{72}$; quanto ao peso das exportações ao Japão e aos Estados Unidos, elas constituíam apenas 7,5\% do PIB chinês em 2000, contra 10 a 20\% na Coréia, na Indonésia, na Tailândia e nas Filipinas, e mais de 40\% na Malásia; todos 
estes países, ao contrário da China, dependem, particularmente, das exportações de semicondutores e de outros produtos das tecnologias de informação, o que lhes deu, nos últimos anos, uma vulnerabilidade exterior muito grande. Assim, o gigante da Ásia oriental conseguiu manter as altas taxas de crescimento das suas exportações e continuou atraindo capitais do exterior, mesmo se reorientando com êxito para um maior investimento e para o consumo interno. ${ }^{73}$.

Tamanho do país, tradições culturais, localização geográfica em uma região dinâmica, política econômica, passado feudo-imperial e capitalista-semicolonial, herança das filosofias do confucionismo e do taoísmo, assim como do revolucionário Mao, do reformador Deng e do manager Jiang Zemin - tudo isso contribui para explicar o resultado atual. A “economia de mercado socialista” levou, por exemplo, a uma presença de capitais estrangeiros cuja utilidade às vezes pode parecer enigmática, como nos casos da produção de chá frio - por uma subsidiária da cervejaria japonesa Santory - ou de água purificada - pela Coca Cola - que são consumidos em quantias astronômicas em garrafas de plástico no calor do verão, sem falar da presença dos incontáveis McDonalds e Kentucky Fried Chicken em concorrência com a deliciosa comida local. Se nas cidades do país, o visitante pode crer que já não existe chinês sem telefone celular e se multiplicam os números de turistas estrangeiros como os cybercafes, isso também é sinal de abertura. A entrada de capitais estrangeiros nas grandes empresas estatais, que parece ter lugar segundo uma lei de outubro de 2002 que permite o controle majoritário destes, deverá significar um passo importante para aumentar a eficiência e, portanto, uma iniciativa essencial para utilizar a adesão à OMC em vista a reforçar a modernização ${ }^{74}$.

O problema principal talvez esteja justamente no plano interno, em relação ao modelo de desenvolvimento que cria tensões crescentes, muitas vezes perigosas. De acordo com Paul Kennedy, “como a China e a Índia possuem uma vantagem tecnológica sobre muitas sociedades em desenvolvimento, caberia ser otimista sobre suas perspectivas, mas com duas dúvidas importantes. A primeira, o núcleo do problema, é se o potencial para o incremento do nível de vida per capita não será aniquilado por milhões de crianças que nascem a cada ano. A segunda questão supõe um cruel dilema: o que é mais sensato para países que possuem entre 500 milhões e um bilhão de camponeses, tentar hoje seguir 'as etapas do crescimento industrial' estabelecidas pela primeira vez nos países de tamanho médio da Europa ocidental há cento e cinqüenta anos ou imitar a revolução de alta tecnologia que surge das muito diferentes estruturas socioeconômicas da Califórnia e do Japão ${ }^{75}$ "?

Como manter o precário equilíbrio entre cidade e campo, regiões dinâmicas e estagnadas, além da combinação perversa do regime de Partido Comunista, baseado ainda num amplo setor de empresas públicas na indústria, com um capitalismo do tipo selvagem? A inquietude cresce no próprio partido sobre o abismo cada vez mais profundo entre regiões costeiras e interiores. A necessidade crescente, 
segundo as previsões, de importar cereais, assim como os problemas ambientais cada vez mais agudos, são fontes de outras preocupações sérias na China: segundo Lester Brown, diretor do Worldwatch Institute, há realmente razões para isso: "Se a China seguir fundamentalmente na via da industrialização copiada do Japão, da Coréia do Sul e de Taiwan, e se esta diminuição das terras cultiváveis continuar, terá perdido cerca da metade destas terras em 2030. Se a população continuar crescendo como previsto em 490 milhões de almas entre 1990 e 2030, a superfície produtora de cereais por pessoa terá passado de 0,08 hectares em 1990 para 0,04 em $2030^{76}$.

Para outros autores, esta previsão é malthusiana demais. De todo modo, “o intenso desenvolvimento que estão experimentando as frutíferas zonas costeiras traduz-se em uma perda de auto-suficiência, enquanto que o incremento no consumo de carne se reflete em maiores necessidades de pastos e cereais para alimentação do gado. Analistas ocidentais afirmam que a superfície dedicada à produção de grãos perde anualmente entre 100.000 e 300.000 hectares, sendo a China, atualmente, importadora de trigo, arroz, milho e soja ${ }^{77}$ ". Lembremos que só 10 ou $15 \%$ das terras chinesas são aptas para a agricultura.

Se a China teve, sem dúvida, grandes êxitos em termos de crescimento econômico, em flagrante contraste com a Rússia e os outros países da Europa Oriental pós-perestroika, isso foi, com certeza, não só por “ter tido sorte” ou por ter rejeitado a terapia de choque proposta pelo establishment ocidental. Foi precisamente por ter empreendido suas reformas liberalizantes de forma gradual e não tão brusca como aqueles países. Assim opinam dois especialistas espanhóis que salientam o entorno geral diferente: "Enquanto a China não sofria graves desequilíbrios macroeconômicos, tinha uma alta proporção de agricultores e efetuava já a maior parte do seu comércio exterior com países de economia de mercado, os países da Europa Oriental e a antiga União Soviética tiveram que fazer frente a um grave descontrole das macro-magnitudes, a uma considerável superindustrialização e à perturbação externa que supôs o colapso do COMECON. Ademais, a China pôde contar com sua pertinência à Ásia oriental, a região mais dinâmica do planeta, com dois pólos de desenvolvimento, Hong Kong e Taiwan, assim como com as contribuições dos chineses de ultramar. Pelo contrário, as economias da Europa central e oriental iniciaram sua transição em uma época de vacas magras no Ocidente e não conseguiram atrair tanto investimento estrangeiro ${ }^{78}$ ”.

Os êxitos do último quarto de século dão à China melhores perspectivas para enfrentar os desafios que não são poucos. Mas o êxito principal terá sido, sem dúvida, o de ter definido seu próprio ritmo e sua própria maneira de realizar reformas, rejeitando receitas vindas de fora que tantos desastres têm provocado em outras partes. A China soube entrar na globalização aproveitando as possibilidades de uma economia mundial mais aberta sem cair nas ilusões de um ultraliberalismo ingênuo ou hipócrita, nem acreditar nas ilusões de mercados 
mundiais "livres" movidos pela "mão invisível” de Adam Smith e uma suposta racionalidade universal. Entendeu que as "vantagens comparativas" de David Ricardo podem servir de orientação de base, mas devem ser interpretadas de forma realista - tendo em conta que o mercado real é mais regido por grandes empresas multinacionais que pela concorrência perfeita ou pela “mão invisível” e em uma perspectiva dinâmica. Se um país atrasado quer progredir, como fizeram outros países asiáticos, requer uma combinação de mecanismos de mercado com sólidas medidas de orientação estatal, sendo esta uma receita muito melhor que aquela confiante nas "funções auto-reguladoras do mercado", ainda constitui o credo básico de instituições como o $\mathrm{FMI}^{79}$.

As experiências asiáticas posteriores a 1997 - após a crise que em boa parte foi resultado da política do FMI, sobretudo por sua insistência dogmática na abertura dos mercados financeiros que causou uma especulação nefasta - mostram também que as receitas posteriores de austeridade e de ainda maior abertura foram erradas $^{80}$. Os países em questão recuperaram-se posteriormente e, tanto radicalmente como rapidamente, rejeitaram estas receitas, como ilustram os casos da Malásia e também da Coréia do Sul. O Banco Mundial tinha reconhecido no seu famoso estudo de 1993, realizado por iniciativa japonesa, que os êxitos asiáticos se explicavam, sobretudo, pelo intervencionismo estatal combinado com mecanismos de mercado, apesar de sua explicação ser baseada em uma distinção pouco convincente entre intervenções favoráveis ao mercado, portanto recomendáveis, e outras que não o seriam $^{81}$. Um especialista filipino descreveu como essa verdadeira "associação ao capital” (estrangeiro) devido à afluência de capitais especulativos causou problemas graves que tenderam a levar estes países de volta ao "Terceiro Mundo 82 ".

O ensaio recente do antigo economista-chefe do Banco Mundial, Joseph Stiglitz, mostra que o Consenso de Washington é crescentemente questionado mesmo dentro do establishment mundial. Juntou-se a ele até o especulador-filósofo George Soros, que denuncia a incoerência, a hipocrisia e a irracionalidade do sistema mundial. As práticas muitas vezes protecionistas dos países ricos são, efetivamente, muito bem ilustradas, em 2002, pelos próprios Estados Unidos, campeões do liberalismo, na agricultura e no setor siderúrgico. Pode-se concluir com o autor que, independentemente das suas enormes vantagens potenciais, a globalização, na forma em que hoje avança, simplesmente "não funciona", nem para os pobres do mundo, nem para o meio ambiente, nem ainda para a estabilidade da economia internacional ${ }^{83}$.

Em uma linha paralela, o especialista espanhol citado no início destas páginas conclui seu artigo recente sobre o acordo de Doha: “Com todas essas limitações, a existência da OMC e da Declaração de Doha servem novamente para evitar que o exercício da hipocrisia multilateral que às vezes supõe o debate livre comércioprotecionismo se converta em uma guerra comercial aberta e que jogue no lixo um 
dos pilares da 'globalização humana' a que hoje devemos aspirar tendo em vista os problemas causados pelo fundamentalismo de mercado ${ }^{84}$ ".

Uma guerra econômica aberta certamente faria vítimas, em particular, e, sobretudo, nos países periféricos. Mas uma abertura radical e reformas liberais podem levar ao desenvolvimento, como também a graves crises ou ao desastre pela fragilidade externa resultante. A globalização oferece grandes possibilidades aproveitáveis para aumentar a produtividade e prosperidade de um país, mas também implica enormes perigos e problemas. Quem, como os “tigres”, se aventura muito longe nessa via pode alcançar taxas de crescimento impressionantes e êxitos também fora dos indicadores puramente econômicos, mas corre riscos. Pode aumentar a sua autonomia, mas também chegar a ser "re-subordinado", adverte um economista filipino, ou ainda, nos tempos de pós-Guerra Fria, até ser vítima de "re-colonização”, como acrescenta um veterano observador indiano de temas internacionais ${ }^{85}$.

A questão que fica em todo caso aberta é a de quais serão os custos e benefícios da integração acelerada na globalização. A especialização internacional traz, teoricamente, benefícios evidentes para todos, mas na prática para alguns, talvez muitos, mas certamente não para todos. Os benefícios são, em todo caso, desigualmente distribuídos entre nações desiguais, levando em consideração uma série de circunstâncias complexas ${ }^{86}$, apesar de existirem "clubes de convergência ${ }^{87}$ " como a União Européia ou, segundo espera o establishment mexicano, o NAFTA. A China, por sua própria força, poderá talvez reduzir os custos e maximizar os lucros, mas isso depende de sua política e de suas respostas concretas aos problemas antes resumidos. Não deveria esquecer que as realidades da globalização são muito distantes dos discursos oficiais predominantes, tendo mais a ver com relações de força, capacidade de inovação, oligopólios, orientação estatal, etc., do que com uma idílica concorrência perfeita onde todos ganham e ninguém perde ${ }^{88}$.

A crescente presença chinesa constitui, por outro lado, uma concorrência que deveria aumentar a vulnerabilidade exterior dos outros países asiáticos, apesar de também poder oferecer-lhes novas oportunidades de especialização. "A maneira que respondem seus vizinhos à chegada da China”, resumem dois especialistas, "determinará se vão prosperar ou não na nova ordem na qual a Ásia estará crescentemente organizada em torno da China ${ }^{89}$ ".

Também para outras regiões relativamente subdesenvolvidas como América Latina ou Europa oriental, a maior presença da China no comércio mundial - e a conseqüente redistribuição dos fatores produtivos em nível mundial - pode ser perigosa, diminuindo as suas possibilidades de exportar têxteis e outros produtos industriais, mas podendo lhes oferecer aumento das exportações de produtos agropecuários, entre outros, à China. Para a Europa e os Estados Unidos, a conseqüência deveria ser, sobretudo, uma maior possibilidade de lucros comerciais e de voltar a equilibrar sua balança comercial atualmente muito deficitária ${ }^{90}$. Isso não exclui, evidentemente, que certos setores nesses países possam sofrer 
duramente o impacto, acelerando a queda de atividades tradicionais e agravando as tensões sociais. A União Européia, por exemplo, opõe-se há muito tempo ao que considera “concorrência desleal” da Coréia quanto à construção de barcos.

Relativamente à China, resta ainda a pergunta de como continuará sua característica de oscilação permanente entre a admiração, o ódio ou desprezo, frente ao "outro" ocidental como afirma um especialista francês: "Por um lado, Pequim tira proveito de forma massiva dos investimentos dos chineses de ultramar e também se beneficia da boa vontade dos diplomatas asiáticos. Mas a China não perde nunca a ocasião de salientar sua desconfiança frente ao Japão e seu desprezo frente aos pequenos países do Sudeste da Ásia. De fato, os dirigentes chineses professam sentimentos muito complexos frente aos seus vizinhos, estabelecem relações com eles quando necessitam, mas, na realidade, não lhes perdoam por terem tido razão".

"No fundo, os sucessores de Deng Xiaoping vão enfrentar uma situação paradoxal, mas compreensível: a crescente abertura de sua sociedade reforça a integração com a Ásia e o mundo; por outro lado, conserva a hostilidade de numerosos chineses frente aos países estrangeiros. Se a economia progredir, as dores da transição serão atribuídas ao estrangeiro. Se deteriorar, também será por culpa da abertura. Nessas condições, saberão os sucessores de Deng Xiaoping realmente como atuar para estabilizar a relação intelectual e política do estrangeiro na China, e, em especial, a do Ocidente? Ou, ao contrário, encorajarão o desenvolvimento do nacionalismo para compensar seu déficit ideológico ${ }^{91}$ "?

É certo que estes sentimentos xenófobos têm profundas causas históricas e que as reticências frente a uma globalização ultraliberal, ou somente liberal, têm também outros motivos: "O governo chinês considera a alimentação da população uma questão de segurança nacional e existe, por isso, um certo temor quanto à dependência externa, especialmente com respeito aos Estados Unidos. Este receio fica plasmado na negativa da China de incluir o setor agrícola no projeto que liberaliza a área comercial Ásia-Pacífico, discutido na terceira cimeira da APEC celebrada em Osaka em novembro de 1995. A partir desta perspectiva, a China se encontra em uma difícil encruzilhada. Tem de optar pela liberalização e a importação ou impor medidas protecionistas semelhantes às estabelecidas pelo Japão e pela Coréia do Sul para proteger seus agricultores. Se a opinião majoritária se inclinar pela proteção, esta decisão entraria em claro conflito com a atual dinâmica liberalizante do bloco asiático, assim como com o cumprimento das condições de acesso à Organização Mundial do Comércio ...92". Isso foi escrito há poucos anos, e a atitude da China frente à OMC aceitando uma abertura parcial e gradual do seu setor agrícola parece refletir sua acostumada tendência ao pragmatismo, apesar de que só o futuro dirá se as precauções terão sido suficientes.

Por último, fica ainda aberta a questão fundamental das vantagens e desvantagens de um sistema político mais aberto. Os êxitos do Japão se deram 
primeiro sob o regime autoritário, mas constitucional, de Meiji que logo se transformou num sistema militarizado aliado à Alemanha de Hitler, e, após 1945, sob uma democracia liberal-conservadora de estilo ocidental imposta pelos vencedores. Os “tigres” imitaram o Japão em muitos aspectos, mas com regimes que não tinham nada de democráticos, apesar de terem feito reformas que levaram a uma distribuição da renda não muito desigual. Outros regimes autoritários como os das Filipinas ou do Paquistão não chegaram a produzir o take-off econômico, criando ou agravando os abismos sociais e tensões regionais que põem em risco a própria coesão nacional. Mas o que se passou na Índia, praticamente o único país da região com instituições democráticas, que se mostrou bem mais estável do que todo o mundo pensava há algumas décadas? Muitos indianos dizem que o seu sistema político não só lhes preservou de graves violações de direitos humanos, de guerras civis ou interétnicas, mas também de aberrações gigantescas - como na China de Mao durante a Revolução Cultural - e de autoritarismos estéreis como os de alguns países vizinhos, e talvez lhes ofereça, em definitivo, melhores perspectivas de longo prazo que os regimes autoritários de outros países asiáticos, inclusive aqueles que têm ostentado altas taxas de crescimento econômico. Os maiores “tigres” Coréia e Taiwan, e em menor medida outros países da região, já se orientaram há vários anos, como corolário do seu desenvolvimento econômico, para um regime político de tipo ocidental.

$\mathrm{Na}$ China, este caminho parece ainda longo e difícil, sobretudo na medida em que o regime mantém certa legitimidade por seu próprio êxito econômico e também devido ao atraso ainda muito grande em termos de "consciência democrática” (ocidental) nas regiões majoritárias, fora dos enclaves modernizantes e arredores, onde foi aparecendo uma crescente, mas ainda muito heterogênea, classe média, isto é, em regiões que contam com uns 400 milhões de habitantes ${ }^{93}$. A ignorância ainda quase total da língua inglesa na China de hoje - que muito lentamente vai diminuindo - reflete essa relativa desconexão do mundo, incomparável internacionalmente, exceto talvez com a Coréia do Norte. Segundo o politólogo estadunidense Robert Dahl, contudo, o êxito econômico da China tem criado ali também as precondições de tal sistema político: classe média, educação e uma maior demanda de informação. "E quando um governo cria estas condições não pode seguir se impondo sem destruir seus próprios objetivos; quer dizer, se frente a uma sociedade que gera demandas de democratização o regime governante se obstina a se impor de modo autoritário, não lhe resta outro caminho que o de destruir esta sociedade ${ }^{94}$ ". Pode ser demasiado contundente esta afirmação, mas reflete, sem dúvida, a grande interrogação política que é a da "quinta modernização”, a do sistema político da China no começo do século XXI. 


\section{Notas}

1 GRANELL, Francesc. Doha, China y la OMC. Del pesimismo al diálogo multilateral. Política Exterior 85. Madrid, p.25-31, jan.-fev. 2002.

2 HOBSBAWM, Eric. Historia del siglo XX, 1914-1991 Barcelona: Crítica, 1995, p. 460.

3 Ilustração eloqüente da nova atitude, a televisão chinesa mostrava com freqüência durante a estada do autor na China em agosto de 2002 destruições de CDs e outros produtos pirateados diante de representantes das autoridades empenhadas em acabar com as práticas tão criticadas como violação de direitos de propriedade intelectual. Todavia, isso não impedia que se pudesse comprar em toda parte excelentes CDs das músicas de Mozart, dos Beatles, etc., pelo módico preço de um ou dois dólares.

4 CHIENG, André. La Chine à l’OMC: promesses, risques et arrière-pensées. Sociétal. Paris, n. 36, $2^{\circ}$ trimestre, p.20, 2002.

5 Após o Japão, apareceram, nos anos 60, os dinâmicos "quatro pequenos tigres" - no início chamados de "dragões” (Coréia do Sul, Taiwan, Cingapura e Hong Kong), e a partir dos anos 70 outros países como Malásia e Tailândia (v. SUKUP, V. Ásia Oriental e Sudeste Asiático modelos para América Latina? Revista Brasileira de Política Internacional, No. 40 (2), p. 27-48, 1997 e Asia frente al siglo XXI - ¿de los “milagros” a las “debacles”? Buenos Aires: Corregidor, 2000.

6 MADDISON, Angus. La economía mundial, 1820-1992. Análisis y estadísticas. Perspectivas OCDE. Paris: 1997.

7 FERRER, Aldo. Historia de la Globalización. Orígenes del orden económico mundial Buenos Aires: FCE de Argentina, 1996, p. 270.

8 FOK, Kai Cheong. Estudos sobre a instalação dos portugueses em Macau. Lisboa: Ed. Museu Marítimo de Macau e Ed. Gradiva, sem data, p. 12.

9 INTRODUÇÃO. Visões da China na literatura ibérica dos séculos XVI e XVII. Antologia documental. Revista de Cultura. Macau, n. 31, dedicado ao tema, abril-junho 1997.

10 Parece que os jesuítas propuseram a Roma a adaptação da simbologia do cristianismo, substituindo o pão pelo arroz e o vinho pelo chá, para atrair os chineses para a religião cristã, mas o Vaticano se opôs a essa idéia, impedindo o possível êxito dos esforços dos missionários que sempre foram vistos mais como vanguarda do colonialismo europeu que como mensageiros da palavra de Deus. Uma maior flexibilidade da hierarquia católica teria talvez mudado o rumo da história.

11 RUSSELL, Bertrand. The Problem of China, Londres: George Allen \& Unwin, 1922, p. 51.

12 PINON, René; DE MARCILLAC, Jean. La Chine qui s’ouvre. París: Librairie académique Perrin \& Cie, 5a éd, 1900, p. 1.

13 Citado por REMER, C. F. The foreign trade of China. Shanghai: The Council Press, 1928, p. 17.

14 Ibid., p. 245.

15 Ibid., p. 233.

16 CHESNAIS, Jean-Claude. La revancha del Tercer Mundo. Buenos Aires: Sudamericana, 1987, p. 63.

17 PEFFER, Nathaniel. China: the collapse of a civilization. Londres: George Routledge \& Sons, 1931, p. 5.

18 MORISHIMA, Michio. Por que ha “triunfado” el Japón. Tecnología occidental y mentalidad japonesa. Caracas: Grijalbo, 1988.

19 PEYREFITTE, Alain. Milagros económicos. Barcelona, México, Buenos Aires, Santiago: Ed. Andrés Bello, 1997, p. 202-3.

20 REINHARD, Marcel; ARMENGAUD, André. Historia de la población mundial. Barcelona: Ariel, 1966, p. 375. 
21 PEYREFITTE, Alain. Quand la Chine s’éveillera, le monde tremblera. París: J’ai lu, 2a ed., 1977.

22 Voie chinoise, voie indienne. Le Monde. 3-10-89.

UL HAQ, Mahbub. La cortina de la pobreza. México: FCE, 1978, p. 70.

BUSTELO, Pablo; FERNANDEZ LOMMEN, Yolanda. La economía china ante el siglo XXI. Veinte años de reforma. Madrid: ed. Síntesis, 1996, p. 49-50.

KRISTOF, Nicholas D.; WUDUNN, Sheryl. China wakes. The struggle for the soul of a rising power. Nueva York: Random House, 1995, p. 16.

YOUNG, Soogil. East Asia as a regional force for globalism. In: ANDERSON, Kym; BLACKHURST, Richard (Orgs.). Regional Integration and the Global Trading System. Nueva York, Londres, Toronto, Sidney, Tokio y Singapur: Harvester Wheatsheaf, 1994, p. 128.

LEMOINE, Françoise. Los riesgos del recalentamiento. Archivos del Presente. Buenos Aires: No. 1 (1), otoño de 1995, p. 65.

28 FOUQUIN, Michel. Asia oriental: las trampas de la liberalización, en SELA, Secretaría permanente - CEPII (Centre d'Etudes Prospectives et d'Information Internationale). 1998: América Latina y Caribe en la Economía Mundial. Buenos Aires: Corregidor, 1998, p. 65 et 68 .

VAN KEMENADE, Willem. China, Hong Kong, Taiwan, Inc. Londres: Abacus, 1997, p. 68. KENNEDY, Paul. Hacia el siglo XXI. Barcelona: Plaza y Janés, 1995, p. 279-80.

HOCHRAICH, Diana. Los desequilibrios del crecimiento en China. Realidad Económica 140. Buenos Aires: maio-junho de 1996, p. 64.

Süddeutsche Zeitung, art. republicado em La Nación, Buenos Aires, 7-7-1997.

BUSTELO, P. Op. cit., p. 52-3.

RIFKIN, Jeremy. The End of Work. The Decline of the Global Labor Force and the Dawn of the Post-Market Era. Nueva York: Tarcher-Putman, 1995.

Neue Zürcher Zeitung, 26-3-93.

China Daily, 30-8-02.

BUSTELO \& FERNANDEZ L., op. cit. , p. 166, 171, 27.

WEGGEL, Oskar. Taiwan - Hongkong. Munich: Beck, 1992.

YACOUP, Joseph. Les minorités dans le monde. Faits et analyses. París: Desclée de Brouwer, 1998, p. 639-654.

40 ROVETTA DUBINSKY, Pablo. El desarrollo del Oeste: la estrategia para el futuro de China. In: China en el siglo XXI, Información Comercial Española. Madrid: n. 797, p. 93-100, fev. 2002

41 International Herald Tribune, 10/11-2-96.

42 KENNEDY, P. op. cit., p. 261.

43 Neue Zürcher Zeitung, 23-9-02.

KRISTOF \& WUDUNN, op. cit., p. 15. O fato bem conhecido que os Estados Unidos, com menos de um quarto da população da China, contribuem muito mais que ela aos problemas ambientais do mundo não impede que as conseqüências do desenvolvimento chinês também sejam objeto de preocupações legítimas. 68.

BUSTELO \& FERNANDEZ L., op. cit., pp. 185-6.

Neue Zürcher Zeitung, 13 e 24-9-02.

Financial Times, 27-9-02.

PO KEUNG, Hui et al. China. In: RAINA, Vinod et al. The Dispossessed. Victims of Development in Asia. Hong Kong: Arena Press, 2a reimpressão, 1999, p. 23-66.

KRISTOF \& WUDUNN, op. cit., p. 431.

VAN KEMENADE, W. op. cit., p. 220. 
ALMEIDA, Paulo Roberto de. Velhos e novos manifestos. O socialismo na era da globalização. São Paulo: ed. Juarez de Oliveira, 1999, p. 41-7.

KRISTOF \& WUDUNN, op. cit., p. 187.

Ibid., p. 222.

Ibid., p. 193.

Ibid., p. 192 ss.

VAN KEMENADE, W. op. cit.

ANTÓNIO, Nelson; ROSA, Álvaro A. da. Macau and the Pearl River Delta: The steps to the global economy. In: RAMOS, Rufino; ROCHA, José DINIS; WILSON, Rex; YUAN, D. Y. (orgs.). Macau and Its Neighbours in Transition. Macau: University of Macau and Macau Foundation, 1997, p. 201-210.

WEI, Wou. The interaction of economic liberalization between Taiwan and Mainland China. In: RAMOS, R. et al. Macau and ..., p. 183-92.

Neue Zürcher Zeitung, 11-10-02.

O novo diretor geral da OMC Supachai também apoiou a adesão da China com o argumento de que ela seria uma ponte entre ambos grupos de países, v. OCCIS, Nicolas. Les enjeux de l'adhésion de la Chine à l’OMC. Politique étrangère. París: n. 4, 2001, p. 983.

Le Monde, 22-2-97.

GODEMENT, François. Cinq enseignements de la crise asiatique. Géopolitique. París: n. 62, p. 23-9.

KRISTOF \& WUDUNN, op. cit., p. 15.

CHIENG, A., op. cit., p. 22.

V. por exemplo GOODMAN, David S. G.; SEGAL Gerald. China without Deng. New York, Amsterdam, Sydney: ed. Tom Thompson, 1995.

CNUCED. Rapport 2002 sur l'investissement. Genebra: 2002.

OMC. International Trade Statistics. Genebra: 2002.

YANG, Yongsheng; ZHONG, Chuanshui. China's Textile and Clothing Exports in a Changing World Economy. The Developing Economies. Tóquio: XXXVI (1), março, 1998.

COLLADO ARMENGOL, Albert. La inversión directa en China: implicaciones derivadas de su entrada en la OMC. Información Comercial Española. Fev. 2002, p. 77-91.

LAMY, Pascal. L'Europe en première ligne. Paris: Seuil-L'épreuve des faits, cap. 1, 2002, p. 13-30.

BUSTELO GOMEZ, Pablo. Evolución reciente y perspectivas de la economía china. Información Comercial Española. 797, fev, 2002, p. 45.

Ibid, p. 47-50.

Financial Times, $10-10-02$.

KENNEDY, P. op. cit. p. 273.

DECORNOY, Jacques. La Chine, le riz et le pare-chocs. Le Monde diplomatique. Nov. 1995. BUSTELO \& FERNANDEZ L., op. cit., p. 67.

BUSTELO \& FERNANDEZ L., op. cit., p. 233.

V., por exemplo, algumas reflexões úteis que vêm do Norte e do Sul: WADE, Robert. Governing the Market: Economic Theory and the Role of Government in East Asian Industrialization. Princeton: Princeton University Press, USA, 1990; WHITE, Gordon (org.). Developmental States in East Asia. Londres, Basingstoke: Institute of Development Studies, Univ. of Sussex, Macmillan Press, 1988; MALHOTRA, Kamal. East and Southeast Asia Revisited: Miracles, Myths and Mirages. In: Focus on the Global South. Bangkok: Focus Papers, Universidad Chulalongkorn, nov., 1997; Rethinking Development. Bangkok: Focus Papers, 1998; ROSEN, George. The State and the Market in Industrial Development: Perspectives from the 1980s. Asian Development Review. Manila, 10 (2), 1992, p. 35-45; BEKERMAN, Marta; SIRLIN, Pablo; STREB, María Luisa. Política económica en experiencias de Asia. Los casos de 
Corea del Sur, Taiwán, Malasia y Tailandia. Buenos Aires: Universidade de Buenos AiresCentro de Estudios de la Estructura Económica, Documento de Trabajo n. 2, 1995.

80 BULLARD, Nicola; BELLO, Walden; MALHOTRA, Kamal. Taming the Tigers: The IMF and the Asian Crisis. In: JOMO, K. S. (org..) Tigers in Trouble. Financial Governance, Liberalisation and Crisis in East Asia. Londres y Nueva York: Zed Books, 1998, p. 85-136.

81 BANCO MUNDIAL. The East Asian Miracle: Economic Growth and Public Policy. Nova Iorque: Oxford University Press, 1993. Para o debate sobre política industrial com uma valoração crítica deste estudo, v. LALL, Sanjaya. Learning from the Asian Tigers. Studies in Technology and Industrial Policy. Londres: Macmillan, 1996, cap. 1.

82 BELLO, Walden. Addicted to capital. The ten-year high and present-day withdrawal trauma of Southeast Asia's economies. Bangkok: Focus Papers, Focus on the Global South, Universidad Chulalongkorn, nov. 1997; Back to the Third World: The Financial Crisis and the Future of East Asia. In Financial crisis: our response. A Deliberation of Regional NGOs in Hong Kong. Hong Kong: Clear Cut Publishing and Printing Co., 15-18, June, 1998, p. 11-7.

83 STIGLITZ, Joseph. La grande désillusion. Paris: Fayard, 2002.

84 GRANELL, F., op. cit., p. 31.

85 BELLO, Walden. Dark Victory - The United States, Structural Adjustment and Global Poverty. Freedom from Debt Coalition. Filipinas, Quezon City: University of the Philippines, 1994, e RAGHAVAN, Chakravarthi. Recolonization. GATT, the Uruguay Round and the Third World. Penang, Malásia: Third World Network, 1990.

86 GRUNDLACH, Erich; NUNNENKAMP, Peter. Catching-up processes or decoupling trends? Developing countries in the age of globalization. In: Economics. Tübingen, Alemanha: n. 55/56, 1997, p. 60-84.

87 CACHEUX, Jacques Lê. Mondialisation économique et financière: de quelques poncifs, idées fausses et vérités, Revue de l’OFCE. In: Problèmes économiques, hors série, março, 2002, repr. 2.772, 14-10-2002, p. 11-15.

88 RAPOPORT, Mario. La globalización económica: ideologías, realidad, historia. Buenos Aires: Ciclos, n. 12, 1997, p. 3-42.

89 SUPACHAI, Panitchpakdi; CLIFFORD, Mark. China and the WTO. Cingapura: John Wiley \& Sons, 2002, p. 137.

90 ALGIERI, Franco; TAUBE, Markus. Chinas Beitritt zur WTO. Herausforderungen für China und die Weltwirtschaft, Dossiê "Machtfaktor China”. In: Internationale Politik. Berlin: 2/2002, p. 33-38.

91 DOMENACH, Jean-Luc. Después de Deng Xiaoping (o el posdenguismo). In: Archivos del presente. Buenos Aires: n. 1 (1), otoño, 1995, p. 63-64.

92 BUSTELO \& FERNANDEZ L., op. cit., p. 68.

93 HEILMANN, Sebastian. Wenig Anlass zu Euphorie. Politische Folgen des Wirtschaftswandels in China, Dossiê “Machtfaktor China”. In: Internationale Politik.Berlin: 2/2002, p. 25-30.

94 La Nación. Buenos Aires: 13-6-99.

\section{Resumo}

Este artigo procura analisar as perspectivas da política externa e interna chinesa e o papel que será exercido pelo país nas próximas décadas. Há inicialmente uma análise histórica da evolução das instituições governamentais chinesas e de como o colonialismo europeu se manifestou na região. Ao final, busca-se entender o papel que essa potência em ascensão terá frente a globalização. 
Abstract

This article seeks to analyse the Chinese foreign and internal policy perspectives and the role that will be played by the country in the next decades. Inicially, there is an historical analyses of the Chinese governmental institutions evolution and how European colonialism occurred in the region. At the end, it seeks to understand the role that this emergent power will play in globalization.

Palavras-chave: China; Hong Kong; Política Externa Chinesa; Globalização. Key-words: China; Hong Kong; Chinese Foreign Policy; Globalization. 